\title{
Environmental Assessment of Water Quality in Kuwait Bay
}

\author{
N. Al-Mutairi, A. Abahussain, and A. Al-Battay
}

\begin{abstract}
Present study aimed to assess the spatial and temporal variations of water quality in Kuwait Bay from six stations between 2009 to 2011 . The results showed that the concentration of phosphorus $\left(\mathrm{PO}_{4}\right)$, nitrate $\left(\mathrm{NO}_{3}\right)$ and dissolved oxygen(DO) fluctuated over time and space. Six stations were significantly grouped into two main classes by cluster analysis, one group located in western side of the Bay and other in eastern side. Three principal component are responsible for water quality variations in the Bay. The first component included $\mathrm{DO}$ and $\mathrm{pH}$. The second included $\mathrm{PO}_{4}$ and $\mathrm{NO}_{3}$, and the last component contained seawater temperature and turbidity. Water quality in Kuwait Bay is influenced by seasonal variations and discharges from point sources of pollution along Kuwait Bay's coast as well as from Shat Al-Arab River. Redesign spatial strategy of monitoring stations is required to cover most degraded areas in Kuwait Bay such Sulaibikhat Bay.
\end{abstract}

Index Terms-Spatial assessment, Kuwait bay, pollution, shat Al-Arab.

\section{INTRODUCTION}

Kuwait's marine environment is a unique ecosystem, characterized by a variety of habitats and wildlife and that clearly manifested in the northern part of Kuwait's waters and Kuwait Bay, the most unique ecosystem in Kuwait's territorial waters. Kuwait Bay is one of the most prominent features of Kuwait's marine environment. Kuwait Bay, a highly productive ecosystem, provides various services including provisioning, regulatory, supporting and cultural services. Kuwaiti waters particularly the Kuwait Bay are rich in a diversity of species that had supplied about $40 \%$ to $50 \%$ of the country's food demand [1]. Based on textural characteristics of its sediments, Kuwait Bay is divided into two energy zones. The first is a low-energy zone that includes most of the Bay, with primarily mud sediment. The other zone is a moderate-energy zone restricted to the southern offshore area with primarily sand and sandy deposits [2]. The maximum current speed was recorded at approximately $1 \mathrm{~m} / \mathrm{s}$ at the Bay entrance, with the currents slowing towards the western portion of the Bay to $<40 \mathrm{~cm} / \mathrm{s}$ [1], [3]. During the last few decades, Kuwait's marine environment experienced adverse incidents on a regional and local scale threatening the quality of water and the ecosystem in general. One of the

Manuscript received January 26, 2014; revised May 6, 2014. This work was supported in part by the Kuwait Environment Public Authority and Arabian Gulf University.

N. Al-Mutairi, A. Abahussain, and A. Al-Battay are with the Department of Environmental and Arid Zones Sciences, Manama, Bahrain (e-mail: geologest_04@ hotmail.com). local stressors is a steady growth in population, effectively doubling in 30 years. Due to the extensive aridity of the land and the lack of agricultural resources, most of population has been forced to concentrate in the coastal zone, particularly the southern coast of Kuwait Bay [4]. To meet the population's needs, many governmental and private sector facilities, such as desalination plants, power plants, recreational facilities, hospitals and other urban and industrial facilities, have been constructed along Kuwait Bay's coast. Most of these facilities discharge their effluent directly into the Bay causing severe burdens on Kuwait Bay ecosystem. On regional scale, the discharges from Shatt Al-Arab also play significant role in variability of water quality of Kuwait marine environment in general and Kuwait Bay in particular [5]-[7]. Kuwait Environment Public Authority (KEPA) regularly has been collecting and monitoring the water quality of Kuwait Bay from six stations cover the Bay since 1985. In recent years, multivariate analyses such as cluster and principle component analysis have been widely applied to evaluate the temporal and spatial characteristics of water quality. Several studies [8]-[11] have classified the monitoring stations based on selected water quality parameters to determine and identify the most stations affected by pollution in a water system. Additionally, cluster analysis has been used to optimize spatial sampling strategies by reducing the number of sampling stations and the costs of analyzing [8], [12], [13]. Principal Component Analysis (PCA) has been widely applied to reduce the amount of water data and summarize the statistical correlations among water quality parameters, with a minimal loss of the original information [14]. PCA, as the multivariate analytical tool, is used to reduce a set of original variables and to extract a small number of latent factors (principal components, PCs) for analyzing relationships among the observed variables [15]. In order to communicate, simplify and reduce the amount of water quality data, Water Quality Index (WQI) was calculated. The aims of study are (i) assessing water quality of Kuwait Bay on spatial and temporal scope. (ii) Identify the main pollution sources affecting the Kuwait Bay ecosystem.

\section{METHODOLOGY}

\section{A. Study Area}

Kuwait Bay (see Fig. 1) is a semi-enclosed shallow body of water extending approximately $35 \mathrm{~km}$ inland. It is an ellipsis-shaped bay at the northwestern edge of Kuwait's territorial waters and covers roughly $750 \mathrm{Km}^{2}$ [16]. The means the water depth of Kuwait Bay is $5 \mathrm{~m}$, and the maximum depth reaches $20 \mathrm{~m}$ at the entrance to the Bay [1]. 


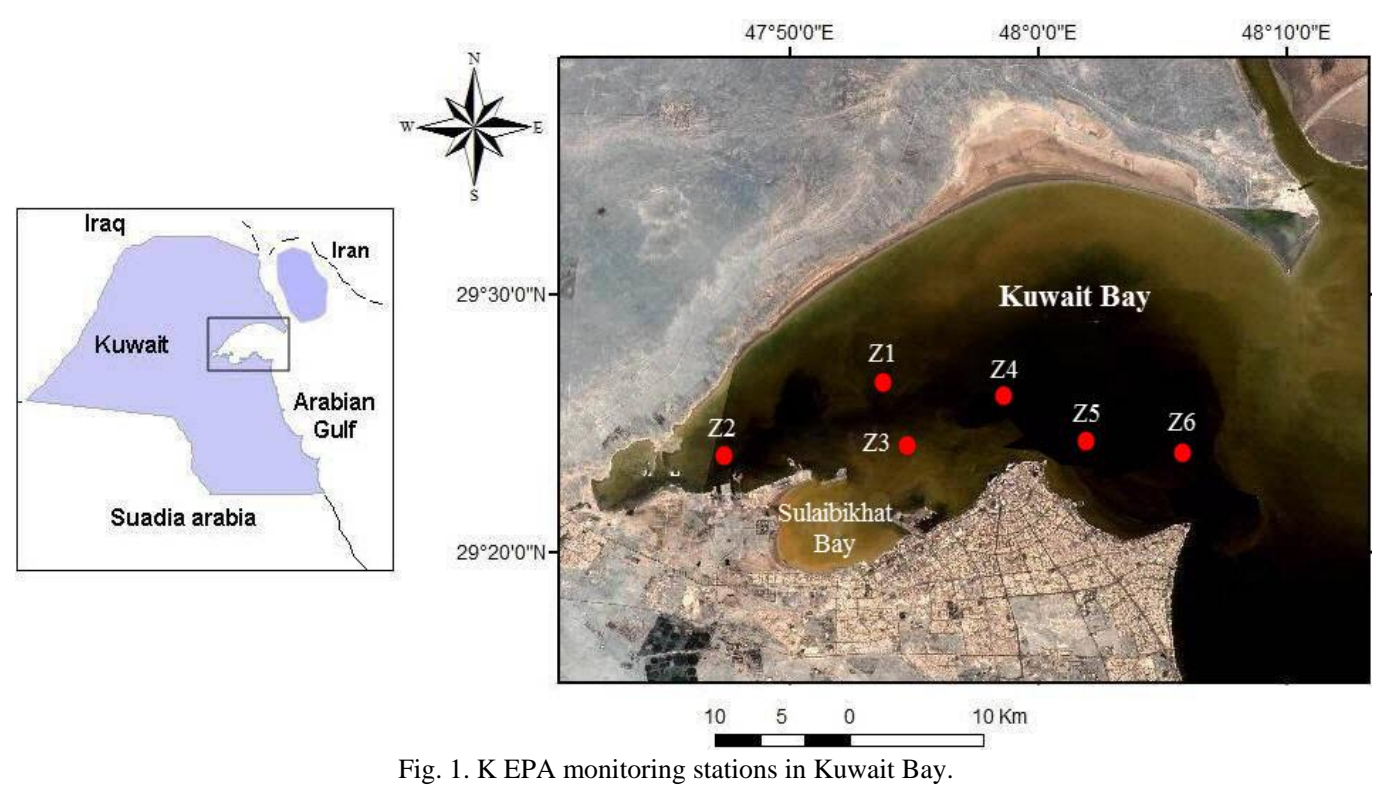

\section{B. Data Source}

The marine water monitoring system of KEPA includes 13 stations throughout the territorial waters of Kuwait, six of which are located in Kuwait Bay. The require data, secondary data, obtained from KEPA for period between January 2009 to November 2011. Water quality data included six parameters: $\mathrm{pH}$, turbidity, Total Suspended Solids (TSS), dissolved oxygen, nitrate $\left(\mathrm{NO}_{3}\right)$, phosphorus $\left(\mathrm{PO}_{4}\right)$ and water temperature. The KEPA data matrix contains 1,260 measurements (34 months, 6 stations, 6 parameters). The hydrolab multi-parameters field instrument was used to measure the $\mathrm{pH}$ and water temperature. The procedures to measure concentrations of turbidity, TSS, dissolved oxygen, $\mathrm{NO}_{3}$, and $\mathrm{PO}_{4}$ were based on reference [17]. The water quality parameters were assessed by KEPA guidelines and standards.

\section{Calculation $W Q I$}

\begin{tabular}{cc} 
TABLE I: WATER QUALITY PARAMETERS AND ITS WEIGHTS \\
\hline \hline Parameters & Weight \\
\hline Dissolved Oxygen & 0.27 \\
pH & 0.18 \\
Total phosphate & 0.16 \\
Nitrates & 0.16 \\
Turbidity & 0.12 \\
Total suspended solids & 0.11 \\
\hline
\end{tabular}

Water quality of Kuwait Bay is assessed using a weighted arithmetic index developed by [18]. Each individual water quality parameter is transformed into a unit-less sub-index value using Q-value charts illustrated by reference [19]. After that, the sub-index for each parameter was multiplied by its weights (Table I). The mathematical expression to calculate overall WQI is given by:

$$
W O I=\sum_{i=1}^{6} W i Q i
$$

where $w i$ is the weight of $i$ th parameter and $Q i$ is sub-index for $i$ th water quality.

\section{Cluster Analysis}

Hierarchical agglomerative cluster analysis (HACA) is commonly used to classify variables (cases) into clusters with high homogeneity within classes and high heterogeneity between classes. In this study, HACA was performed on the normalized data, using Euclidean distances to measure the similarity among parameters, and Ward's method to link the clusters to each other [20].

\section{E. Principal Component Analysis (PCA)}

PCA has been widely applied to reduce the amount of water data and summarize the statistical correlations among water quality parameters, with a minimal loss of the original information [14]. PCA, as the multivariate analytical tool, is used to reduce a set of original variables and to extract a small number of latent factors principal components for analyzing relationships among the observed variables [15]. Before applying principal component analysis, the data must be examined for suitability using Kaiser-Meyer-Olkin (KMO) statistics and the Bartlett's test. Those tests are measures of sampling adequacy that use the proportion of variance. The KMO value must be greater than 0.5 , and the significance level of the Bartlett's test must be less than 0.05 [22], [23].

The number and importance of uncorrelated principal components extracted from the water quality parameters are presented in a scree plot. When the eigenvalue of a principal component is equal to, or greater than, 1 , the result of the principal component analysis is considered significant [24], [25]. To minimize the variations among the variables for each factor, the factor axes were varimax-rotated. Rotating the principal components can produce a meaningful representation of the underlying factors by decreasing the contribution of variables with minor significance and increasing the contribution of those with more significance [26].

\section{RESULTS AND DISCUSSION}

\section{A. Summary Statistics of Water Quality Parameters}

Table II represents summary statistics of water quality 
parameters of Kuwait Bay. The mean dissolved oxygen concentration is $5.8 \mathrm{mg} / \mathrm{l}$, with a wide range of $2.14 \mathrm{mg} / \mathrm{l}$ during February 2009 to $9.73 \mathrm{mg} / \mathrm{l}$ during December 2011.

TABLE II: SUMMARY STATISTICS OF WATER QUALITY IN KUWAIT BAY

\begin{tabular}{|c|c|c|c|c|c|}
\hline & standard & Unit & Mean & Max & Min \\
\hline DO & 4 & $\mathrm{mg} / \mathrm{l}$ & $5.8 \pm 1.45$ & 9.73 & 2.1 \\
\hline $\mathrm{pH}$ & $6.5-8.5$ & -- & $8.4 \pm 0.03$ & 9.79 & 7.7 \\
\hline Temp. & - & ${ }^{\circ} \mathrm{C}$ & $23.8 \pm 0.46$ & 34.8 & 12 \\
\hline Tur. & - & NTU & $15.6 \pm 23.7$ & 123 & $0 *$ \\
\hline TSS & 32.8 & $\mathrm{mg} / \mathrm{l}$ & $14.1 \pm 4.06$ & 29.1 & 7.6 \\
\hline $\mathrm{NO}_{3}$ & 94.7 & $\mu \mathrm{g} / 1$ & $14.9 \pm 28.4$ & 349.31 & $0^{*}$ \\
\hline $\mathrm{PO}_{4}$ & 33.7 & $\mu \mathrm{g} / \mathrm{l}$ & $52.8 \pm 129.2$ & 1434.3 & $0^{*}$ \\
\hline \multicolumn{6}{|c|}{$\begin{array}{l}\text { Temp. = Temperature } \\
\text { Tur. = turbidity } \\
\text { TSS = Total Suspended Solids } \\
\text { *Undetectable limit }\end{array}$} \\
\hline
\end{tabular}

Occasionally, low values of dissolved oxygen are associated with organic matter degradation or low mixing of the water column, particularly during hot and calm summer months [1]. Maximum concentration of dissolved oxygen was recorded at station Z05 which is located near to Arabian Gulf where water mixing well. The concentrations of dissolved oxygen during red tide outbreak on October 1999 ranged from 3.07 to $5.05 \mathrm{mg} / \mathrm{l}$ [27]. Mostly, high dissolved oxygen concentrations are associated with peak primary production rates [1]. The dissolved oxygen in Kuwait Bay was distributed uniformly across depths [28]. As it known, the dissolved oxygen is an important indicator of aquatic life and water quality. The variability of dissolved oxygen has noticeable effects on behavioral process in fish such as feeding, swimming and migration [29]. The dissolved oxygen concentrations reached critical levels, below KEPA standard, for all six stations, indicating heavy pollution, possibly due to Mishref pump station broke down in late 2009. Prior the Mishref station breakdown, huge quantities of sewage were discharged into marine environment to reduce the overload on station.

The mean $\mathrm{pH}$ in Kuwait Bay is 8.4 ranged from 7.7 to 9.8, nearly within the range documented by reference [1]. The maximum value was recorded at station Z03 in December 2010, while the minimum value was reported at station Z06 in October 2010. The spatial variation in $\mathrm{pH}$ values is not statistically significant, indicating the high buffering capacity of Kuwait's waters. There are no significant differences in the $\mathrm{pH}$ values with depth [1]. The range 6.5-8.5 is acceptable according to KEPA standards.

The mean seawater temperature of Kuwait Bay is $23.8^{\circ} \mathrm{C}$, with a minimum of $12.38^{\circ} \mathrm{C}$ in January 2009 and a maximum of $34.8{ }^{\circ} \mathrm{C}$ in August 2010. Highest seawater temperature reported was $36^{\circ} \mathrm{C}$ in August 2001 [1] before a massive fish kill event in September. Fluctuations in seawater temperatures (up to $24^{\circ}$ ) mainly due to seasonal variations. Reference [1] stated that the seasonal difference could exceed $25^{\circ} \mathrm{C}$. The vertical stratification in seawater temperatures with depth was reported at stations deeper than $12 \mathrm{~m}$ depth with difference between surface and bottom layers about 6
${ }^{\circ} \mathrm{C}$. Anthropogenic activities have significant impacts on marine environment by increasing seawater temperature. Reference [30] found that the seawater temperature in Kuwait Bay has increased by an average $0.6{ }^{\circ} \mathrm{C}$ per decade, about three times higher than the global average rate reported by the Intergovernmental Panel on Climate Change (IPCC). Moreover, he concluded that desalination and power plants contribute by $13 \%$ of decadal increasing in the seawater temperature in Kuwait Bay. Seawater temperature is one of the key indicators that affect directly the marine fauna and flora and alter its life [31]. High seawater temperature weakens the immune system of low-tolerance fishes and creates unfavorable conditions making potential events of massive Fishkill [32].

Regarding to water clarity, the mean turbidity of Kuwait Bay is 17.1 NTU, with a range of 0 NTU (undetectable) to 123 NTU. The highest turbidity found in waters at station Z06 located at the entrance to the Bay. The mean concentration of TSS in waters of Kuwait Bay is $14.1 \mathrm{mg} / \mathrm{l}$, with a maximum of $29.1 \mathrm{mg} / \mathrm{l}$ at station Z05 in July 2010 and a minimum of $7.6 \mathrm{mg} / \mathrm{l}$ at station Z01 in December 2009. Although the waters at station Z05 are distant from most emergency outlets, other pressures, such as reclamation and dredging of the coast, influence the water quality at this station. Reference [33] stated that the water clarity in Kuwait Bay was very low compared to other regional waters, and the waters in the center of the Bay and at its southern entrance exhibited the highest turbidity level in the Bay throughout the year. The water clarity of Kuwait Bay is predominantly affected by turbid water discharged from Shatt Al-Arab [34], [16]. Furthermore, coastal currents, resuspension of bottom sediment and dust storms in summer also play significant roles in decreasing the clarity of Kuwait Bay's waters [6].

Concerning nutrients, the mean concentrations of $\mathrm{NO}_{3}$ and $\mathrm{PO}_{4}$ in Kuwait Bay were $14.9 \mu \mathrm{g} / \mathrm{l}$ and $52.5 \mu \mathrm{g} / \mathrm{l}$, respectively. The maximum concentration of NO3, 349.31 $\mu \mathrm{g} / \mathrm{l}$, was documented at station Z03 in January 2009. Annual mean concentration of nitrates in Kuwait waters during 2003 to 2006 was $3.7 \mu \mathrm{g} / \mathrm{l}$ with a range of $<0.1-111.27 \mu \mathrm{g} / \mathrm{l}$ [7]. The level of nitrates are higher in northern water and gradually decrease southward with increasing distance to freshwater influx. The maximum concentration of $\mathrm{PO}_{4}$, $1434.3 \mu \mathrm{g} / \mathrm{l}$, was recorded at station Z05 in November 2009. It was believed that this extreme value in nitrate and phosphate was due to huge quantities of raw sewage discharged into Kuwait Bay via emergency outlets during breakdown of Mishref sewage station in August of 2009. It worth to state that concentration of nutrients $\left(\mathrm{NO}_{3}\right.$ and $\left.\mathrm{PO}_{4}\right)$ during two months after Mishref station breakdown have registered high levels in all stations. Generally, nutrients concentrations are highest during winter and spring, as found by reference [1].Water discharged from Shatt Al-Arab is one of primary sources of nutrients in northern area of Arabian Gulf [35], [7], [1]. Moreover, anthropogenic activities, such as discharge of desalination and power plant effluents as well as partially or raw sewage from emergency and storm outlets are Considerably contributing in increasing the input of nutrients in small and vulnerable ecosystem.

\section{B. Clustering KEPA Monitoring Stations}

The monitoring stations of Kuwait Bay were classified into 
two main clusters based on WQI values using KEPA data (Fig. 2). The first group included stations Z01, Z02 and Z03, which are located in the western part of the Kuwait Bay. This area is characterized by shallow and turbid waters as well as slow dilution (Al-Ghadban and El-Sammak, 2005). The water quality at these stations are under pressures of anthropogenic activities mainly from desalination and power plants, ports, recreational, emergency, and water storm outlets. The monitoring stations of the second group (Z04, Z05 and Z06) are located at the eastern portion of Kuwait Bay. The water in this area is exchanged with fresh seawater from the Arabian Gulf at high rate (Al-Yamani et al., 2004). Recreational activities and developments through reclamation and dredging along the coast are the major types of anthropogenic pressures, along with emergency outlets. The water quality at monitoring stations in cluster two is slightly better than that in the first cluster, in terms of type and quantity of anthropogenic activities, and the natural setting. The KEPA monitoring stations in Kuwait Bay could be reduced from six stations to two, reflecting the shortage of spatial covering of KEPA monitoring stations.

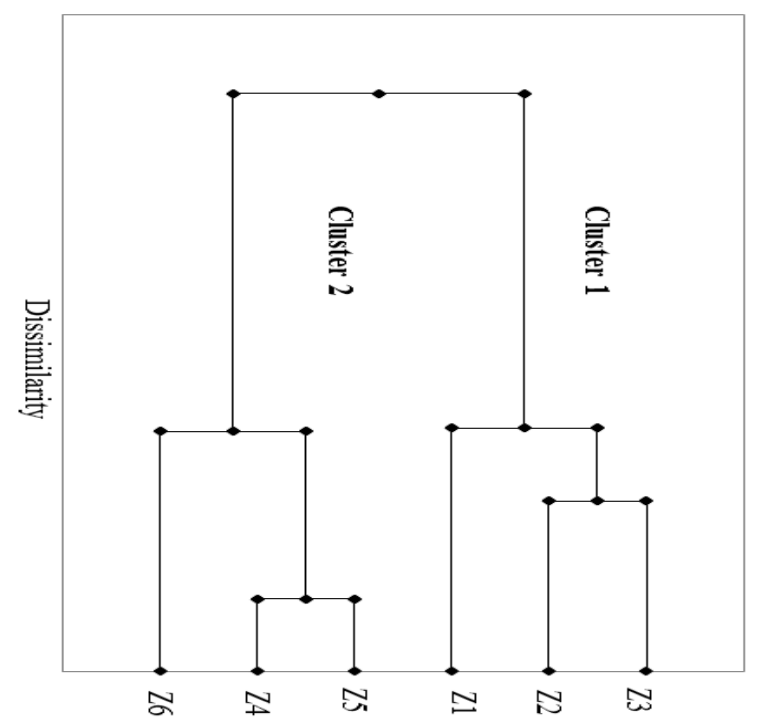

Fig. 2. Dendrogram of monitoring stations according WQI.

\section{Principal Components in Kuwait Bay}

The results of suitability showed positively sings to conduct PCA. The KMO result was 0.53, and Bartlett's test was significant $(p<0.000)$. The Fig. 3 shows the scree plot of eigenvalues for each component produced from PCA. The significant components are the factors that explain the most variation of water-quality in Kuwait Bay. The contribution of each principal component and its Eigenvalue after rotation is presented in Table III. The first three principal components are the most significant principals, which represent $57.9 \%$ of the variance in water quality of the Kuwait Bay. The first component explains $23.87 \%$ of variance in the water quality of the Kuwait Bay, while the second and third components interprets $18.3 \%$ and $15.68 \%$, respectively, of variance in the water quality. Table 5 represents the correlation coefficient between loading of each parameter and their principal components after rotation. Principal component 1 contributes to $23.87 \%$ of the variation, and is highly influenced by $\mathrm{pH}$ and dissolved oxygen. Principal component 2 is responsible for $18.3 \%$ of the variance and is moderately influenced by $\mathrm{PO}_{4}$, TSS and $\mathrm{NO}_{3}$. The second principal component mainly describes nutrient-rich water discharged mostly from emergency outlets and the impacts of anthropogenic activities along the southern coast. The impacts of river discharge, however, have less effect than those of local pollution sources. The third Principal component regulates $15.68 \%$ of variance and had moderate loading on turbidity and $\mathrm{NO}_{3}$ and strong negative loading on water temperature. The presence of the $\mathrm{NO}_{3}$, in two different principal components suggests that there are several sources of nitrogen inputs into the Kuwait Bay ecosystem. The water discharged from Shatt Al-Arab is turbid and nutrient rich [1], [7], and that explains the correlation between turbidity and $\mathrm{NO}_{3}$ in $\mathrm{PC} 3$.

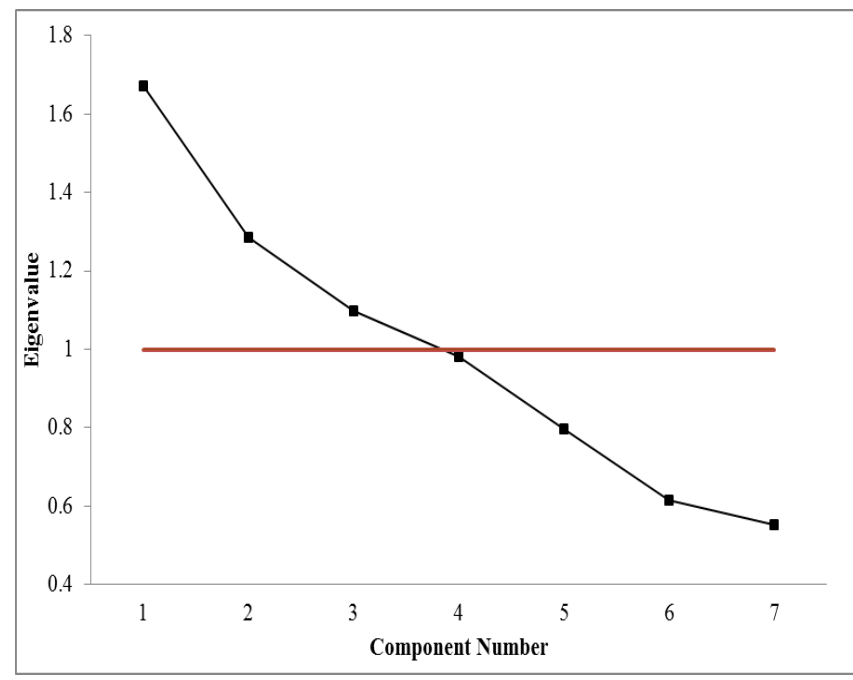

Fig. 3. Scree plot on significant principal component.

TABLE III: ROTATED COMPONENT MATRIX

\begin{tabular}{l|lll}
\hline \hline \multirow{2}{*}{ Component } & \multicolumn{3}{|c}{ Eigenvalues } \\
\cline { 2 - 4 } & 1 & 2 & 3 \\
\hline Water temp. & -0.288 & 0.064 & -0.731 \\
TSS & -0.109 & 0.61 & -0.367 \\
DO & 0.799 & 0.026 & -0.062 \\
pH & 0.828 & 0.046 & 0.112 \\
$\mathrm{NO}_{3}$ & 0.045 & 0.584 & 0.576 \\
$\mathrm{PO}_{4}$ & 0.123 & 0.777 & 0.097 \\
Turbidity & -0.165 & 0.058 & 0.585 \\
\hline \hline
\end{tabular}

\section{CONCLUSIONS AND RECOMMENDATIONS}

Kuwait Bay is suffering from different kinds of pollutions either from local or regional sources. Most significant influencing factors are desalination and power plant, and sewage outlets along southern coast of Kuwait Bay. In August 2009, the Mishrif sewage pumping station was brokedown due to overload, and huge amount of raw sewage were discharged via emergency outlets into seawaters and Kuwait Bay. The impacts of these incidents was so clear in water quality. Most of water quality parameters were 
significantly recorded lower values comparing to previous year. Furthermore, the nutrient-rich waters discharged from Shatt Al-Arab negatively or positively affects the Kuwait marine environment particularly Kuwait Bay.

The locations of KEPA monitoring stations have not been updated since 1985. So, the monitoring system needs to develop its spatial strategy for monitoring stations to appropriately cover Kuwait Bay and investigate the impacts of anthropogenic activities that recently took place.

\section{ACKNOWLEDGMENT}

Authors would like the Kuwait environment public authority for supporting required data, and Arabian Gulf University for using their statistical lab.

\section{REFERENCES}

[1] F. Y. Al-Yamani, J. Bishop, E. Ramadhan, M. Al-Husaini, and A Al-Ghadban, Oceanographic Atlas of Kuwait's Waters, Kuwait Institute for Scientific Research, Kuwait, 2004.

[2] F. I. Khalaf, A. N. Al-Ghadban, S. Al-Saleh, and L. Al-Omran, "Sedimentology and mineralogy of Kuwait bay bottom sediments, Kuwait-Arabian Gulf," Marine Geology, vol. 46, pp. 71-99, 1982.

[3] T. Pokavanich and K. Al-Banaa, "Role of water temperature variability to water circulation in an arid meso-tidal shallow bay in Kuwait," in Proc. 8th International Conference on Coastal and Port Engineering Developing Countries, IIT Madras, Chennai, India, Feb. 20-24, 2012.

[4] A. N. Al-Ghadban, N. Al-Majed, and S. Al-Muzaini, "The State of Marine Pollution in Kuwait: Northern Arabian Gulf," Technology, vol. 8, pp. 7-26, 2002.

[5] N. Y. Khan, "Integrated management of pollution stress in the Gulf," in Protecting the Gulf's Marine Ecosystems from Pollution, A. H Abuzinada, H. J. Barth, F. Krupp, B. Boer, and T. Z. Abdessalaam, Eds. Birkhäuser Basel, 2008, pp. 57-92.

[6] A. N. Al-Ghadban and A. El-Sammak, "Sources, distribution and composition of the suspended sediments, Kuwait Bay, Northern Arabian Gulf," Journal of Arid Environments, vol. 60, 647-661, 2005.

[7] F. Y. Al-Yamani, "Importance of the Freshwater Influx From the Shat Al-Arab River on the Gulf Marine Environment" in Protecting the Gulf's Marine Ecosystems from Pollution, A. H. Abuzinada, H. J. Barth, F. Krupp, B. Boer, and T. Z. Abdessalaam, Eds. Birkhäuser Basel, 2008, pp. 207- 222.

[8] K. P. Singh, A. Malik, and S. Sinha, "Water-quality assessment and apportionment of pollution sources of Gomti river (India) using multivariate statistical techniques - A case study," Analytica Chimica Acta, vol. 538, pp. 355-374, May 2005.

[9] N. Ozbay, S. Yerel, and H. Ankara, "Investigation of Cluster Analysis in Surface Water in Yesilirmak River," in Proc. $1^{\text {st }}$ International Symposium on Sustainable Development, Sarajevo, Bosnia and Herzegovina, 2009, pp. 237-240.

[10] S. R. Kamble and R. Vijay, "Assessment of water-quality using cluster analysis in coastal region of Mumbai, India," Environ Monit Assess, vol. 187, pp. 321- 332, 2011.

[11] C. K. Yab, S. Chee, S. Shamarina, F. B. Edward, W. Chew, and S. G. Tan, "Assessment of surface water-quality in the Malaysian coastal waters by using multivariate analyses," Sains Malaysiana, vol. 40, 1053-1064, 2011.

[12] C. Yongqian, S. Qianwu, and M. Hongmei, "Research on optimization of water-quality monitoring sites using principal component analysis and cluster analysis," in Proc. the 2011 International Conference on Computer Distributed Control and Intelligent Environmental Monitoring, DC, USA, IEEE Computer Society Washington, 2011, pp. 570-573.

[13] M. G. Nabeel, K. Y. Mohd, F. R. Mohammad, Z. A. Ahmad, and J. Hafizan, "Characterization of spatial patterns in river water-quality using chemometric pattern recognition techniques," Marine Pollution Bulletin, vol. 64, pp. 688-698, 2012.

[14] B. Helena, R. Pardo, M. Vega, E. Barrado, J. Fernandez, and L. Fernandez, "Temporal evolution of ground-water composition in an Alluvial Aquifer (Pisuerga River, Spain) by principal component analysis," Water Re-search, vol. 34, pp. 807-816, 2000.

[15] R. Mahmud, N. Inoue, and R. Sen, "Assessment of irrigation water-quality by using principal component analysis in an arsenic affected area of Bangladesh," J .Soil .Nature, vol. 1, pp. 8-17, 2007.
[16] A. N. Al-Ghadban, "Assessment Suspended Sediment in Kuwait Bay Using Landsat and Spot Images," Kuwait, J. Sci. Eng., vol. 31, pp. 155-172, 2004.

[17] Manual of Oceanographic Observations and Pollutant Analyses Methods, ROPME, Kuwait, 1999.

[18] R. M. Brown, N. I. McClelland, R. A. Deininiger, and R. G. Tozer, "A Water-quality Index Do We Dare?” Water and Sewage Work, vol. 117, pp. 339-343, 1970.

[19] W. R. Ott, Environmental Indices: Theory and Practice, University of Michigan, Ann Arbor Science, 1978.

[20] P. Praus, "Urban water-quality evaluation using multivariate analysis," Acta Montanistica Slovaca, vol. 2, pp. 150-158, 2007.

[21] E. Fataei and S. Shiralipoor, "Evaluation of surface water-quality using cluster analysis: A case study," World Journal of Fish and Marine Sciences, vol. 3, pp. 366-370, 2011

[22] M. L. Wu, Y. S. Wang, C. C. Sun, H. Wang, J. D. Dong, J. P. Yin, and S. H. Han, "Identification of coastal water-quality by statistical analysis methods in Daya Bay, South China Sea," Mar Pollut Bull, vol. 60, pp. 852-860, 2010.

[23] S. Gyawali, K. Techato, C. Yuangyai, and S. Monprapusson, "Evaluation of Surface Water-quality using Multivariate Statistical Technique: A Case Study of U-tapao River Basin, Thailand," KMITL Sci. Tech. J., vol. 12, pp. 7-20. 2012.

[24] A. H. Pejman, G. R. Bidhendi, A. R. Karbassi, N. Mehrdadi, and M. Bidhendi, "Evaluation of spatial and seasonal variations in surface water-quality using multivariate statistical techniques," Int. J. Rnviron. Tech., vol. 6, pp. 467-476, 2009.

[25] A. Z. Garizi, V. Sheikh, and A. Sadoddin, "Assessment of seasonal variations of chemical characteristics in surface water using multivariate statistical methods," International Journal of Environmental Science and Technology, vol. 8, pp. 581-592, 2011.

[26] Y. K. Kebede and T. Kebedee, "Application of principal component analysis in surface water-quality monitoring," in Principal Component Analysis - Engineering Applications, P. Sanguansat, Ed. ch. 5, pp. 83-100, 2012.

[27] C. A. Heil, P. M. Glibert, M. A. Al-Sarawi, M. Faraj, M. Behbehani, and M. Husain, "First record of fish killing gymnodinium sp. bloom in Kuwait Bay, Arabian Sea, chronology and potential causes," Mar. Ecol. Prog. Ser., vol. 214, pp. 15-23, 2001.

[28] F. Al-Yamani, D. V. Rao, A. Mharzi, W. Ismail, and K. Al-Rifaie, "Primary production off Kuwait, an arid zone environment, Arabian Gulf," International Journal of Oceans and Oceanography, vol. 1, pp 67-85, 2006.

[29] J. C. Davis, "Minimal dissolved oxygen requirements of aquatic life with emphasis on Canadian species: a review," J. Fish. Res. Bd. Can., vol. 32, pp. 2295-2332, 1975.

[30] T. B. Al-Rashidi, H. I. El-Gamily, C. L. Amos, and K. A. Rakha, "Sea surface temperature trends in Kuwait Bay, Arabian Gulf," Natural Hazards, vol. 50, pp. 73-82, 2009.

[31] K. H. Mann and J. R. Lazier, Dynamics of Marine Ecosystems. Biological-Physical Interactions in the Oceans, $3^{\text {rd }}$ edition. MA and Oxford, UK, Blackwell, 2005.

[32] A. Al-Marzouk, K. Duremdez, Y. Sameer, H. Al-Gharabally, and B. Munday, "Fish kill of mullet Liza klunzingeri in Kuwait Bay: The role of Streptococcus agalactiae and the influence of temperature," in Diseases in Asian Aquaculture, P. Walker, R. Lester, and M. G Bondad-Reantaso, Eds. pp. 143-153, Manila, 2005.

[33] M. Al-Sahli, "Characterizing surface temperature and clarity of Kuwait's sea waters using remotely sensed measurement and GIS analyses," PhD. Dissertation, Dept. Geography and Graduated, Kansas Univ., USA, 2009.

[34] T. Saeed, A. N. Al-Ghandban, H. Al-Shemmari, M. Al-Mutair, and H. Al-Hashash, "Preliminary assessment of the impact of draining of Iraqi marshes on Kuwait's northern marine environment, Part II: Sediment associated pollutants," Water Science and Technology, vol. 40, pp 89-98.

[35] J. K. Abyach, S. A. Darmoian, and A. A. Doubdul, "The shatt Al-Arab River: A nutrient salt and organic matter source to the Arabian Gulf," Hydrobiologia, vol. 166, pp. 217-224, 1988.

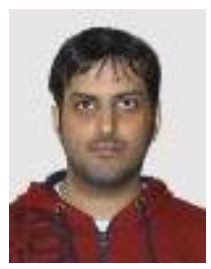

N. Al-Mutairi is a M.Sc student in Arabian Gulf University. M. Nawaf got a bachelor degree in geology from Kuwait University in 2004. He then joined the State of Kuwait Ministry of Education. In 2010 he got a scholarship for Kuwait State to pursue his postgraduate studies at Arabian Gulf University-Desert and Arid Zone Program, Environment and Natural Resources specialization. 


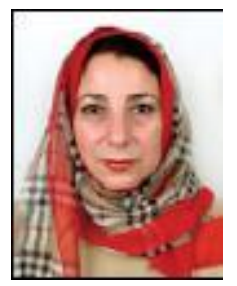

Asma Abahussain is an associate professor in geology/geochemistry in Arabian Gulf University.

Dr. Asma got her geochemistry of sedimentary rocks BSc. degree in 1980 from Baghdad University; earth science MSc. degree in 1983, and PhD degree in 1987. Currently, Dr. Asma is an associate professor of Geology, Geochemistry, Desert and arid Zones Sciences Program (DAZP), College of Graduate Studies, Arabian Gulf University (AGU). Since she joined AGU in 1988, She has supervised or co-supervised more than 40 Masters Theses, and has published more than 30 papers in refereed journals. Seven of her scientific research papers won awards at GCC and Arab Region. Dr. Abahussain served as a consultant and a resource person for Division of Early Warning \& Assessment -West Asia UNEP/ROWA in the field of Integrated Environmental Assessment. Trainer in more than 25 IEA of UNEP Workshops on Environmental Indicators, Analysis of Environmental Policies, Dynamic modeling in support of Environmental Scenarios. She was selected by UNEP to be a member of two GEO-5 global working groups 2012 namely: Data and Indicators and Science and Policy Advisory Board. Locally in Bahrain, she was a member environment committee in the Bahrain
National Planning Development Strategies 2030; editor of the first Bahrain SOE Report, head of Women and Environment Committee in the National Strategy for Bahraini women's; Bahrain Environmental Strategy, head of the Studies and Research Committee in the National Combating Desertification Committee and other specialized committees.

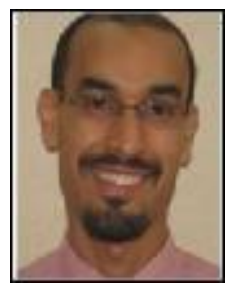

A. Al-Battay is an assistant professor in remote sensing in Arabian Gulf University.

Dr. Ali Elbattay got his $\mathrm{PhD}$ degree in environmental SAR specialization from INRS-ete, Canada in 2006. He joined the Faculty of Geo-information Science and Engineering at Universiti Teknologi Malaysia in 2007 as a researcher then lecturer and subsequently senior lecturer. In 2011, Dr. Ali joined Arabian Gulf University as an assistant professor in remote sensing at College of Graduate Studies. His research interests are in theoretical aspects of proactive remote sensing as well as remote sensing applications for solar energy harnessing. 